DOI: http://dx.doi.org/10.11157/sites-vol11issiid240

- ARTICLE -

\title{
THE ASSOCIATION OF CRIME STORIES AND MĀORI IN AOTEAROA NEW ZEALAND PRINT MEDIA
}

\author{
Tim McCreanor, Jenny Rankine, Angela Moewaka Barnes, Belinda Borell, \\ Ray Nairn, \& Anna-Lyse McManus
}

\begin{abstract}
The association of Māori and crime was prominent in a large representative sample of newspaper items gathered in Aotearoa New Zealand between November 2007 and April 2008. We used content, thematic/discursive analyses as well as focus group insights to analyse the data-base and found that Māori were frequently labelled as possible or actual perpetrators of crime on superficial judgements, often by victims. This practice associates Māori with all accounts of crime and embeds crime as a background for all other items about Māori. In contrast, newspaper coverage of Pākehā perpetrators of crime against a Māori organisation worked to valorise the convicted thieves. The embedding of crime as a background to other stories about Māori, the pervasive but unacknowledged norms, and media positioning of Māori as a threat in non-crime stories, is central to hegemonic discourses of Māori-Pākehā relations. Focus group participants indicated that these discourses support realworld marginalisation and discrimination against Māori.
\end{abstract}

\section{INTRODUCTION}

Mass media are central to the production and maintenance of social order, creating news products that penetrate deeply into all areas of social and psychological life, shaping the discursive resources we use to interpret and make sense of our everyday experiences (Chamberlain and Hodgetts 2008; Fiske 1994; Hartley 1982; McGregor and Comrie 2002; Phelan and Shearer 2009; Philo 2007). These actions sit within an 'occupational ideology' (Deuze 2004) that has journalists understand themselves as neutral, objective observers of society. Critical scholars of the media have long contested this framing, although as Hall $(1977,346)$ has said, the notion of objectivity is now so deeply entrenched that: '...the ideological inflection of media messages [is] best un- 
derstood, not as 'partisan' but as fundamentally oriented within the mode of reality of the state'.

Coverage of crime is a particular invidious instance of media constructions of social reality. Research in the UK (Hall 1977; Nickels et al. 2012), Australia (Ewart 1997; McCallum 2007; Thomas and Green 2009), Canada (Furniss 2001; Henry and Tator 2002) and USA (Freng 2007; Ramasubramanian 2011; Warren 2012) identifies discourses of marginalisation and denigration of minority communities exploited in constructing those citizens as threatening and needing to be controlled. As van Dijk noted in his discursive study of the British press: 'As soon as black people are somehow associated with a breach of the law, such events become newsworthy, although the same crime committed by whites would be ignored or played down' (van Dijk 1991, 98-99).

Such portrayals of minority group members have serious impacts on the beliefs and actions of both in- and out-group members and, consequently, are destructive of positive social relations between individuals and groups. For example, it is argued that racism, in this instance in the media, is a preventable social determinant of health disparities (CsDH [Commission on Social Determinants of Health] 2007; Paradies and Williams 2008). In a context of increasingly mediated intergroup relations, our orientation to media as contributing to this landscape takes on considerable urgency.

In this article we examine literature on the reporting of crime and indigenous people, before narrowing the focus to Māori, as a foundation for content, thematic and discursive analyses of media data that we link to audience perceptions via focus group data. Our aim is to raise media racism as a destabilising element in the wider social relations of Aotearoa New Zealand (Gregory et al. 2011), and to deconstruct journalism practice to highlight its contribution to colonial hegemony.

\section{BACKGROUND}

Large scale European migration to Aotearoa New Zealand from 1840 onwards resulted in 170 years of colonisation and the imposition of a settler state upon the indigenous Māori society (Ballara 1986; Belich 1996; King 2003; Walker 2004). Systemic racism, discrimination and exclusion have been extremely disruptive to Māori social orders, and the alienation of land, language and culture has resulted in social, cultural and economic marginalisation in contemporary Aotearoa New Zealand (Walker 2004; Reid and Robson 2007). The rationale for creating English sovereignty and authority was greatly aided by the general 
colonial practice of representing the indigenous people as savage, uncivilised, deviant and criminal which is evident in highly inaccurate and biased early accounts of the country such the New Zealand Company's publication for colonists. 'The spirit of revenge is implacable in their breast... they kill and sometimes eat their vanquished enemies ... Many of them are covetous ... they thieve with little scruple. The licentiousness of the women is subjected to no restraint until after marriage' (Ward 1839, 63).

The lines from Ward are also an example of the use of media in all available forms to promulgate a reality that fitted migrant English sensibilities and constructed social relations in ways that naturalised the ascendancy of the settlers as a consequence of their presumed inherent superiority. Colonial news media have historically promoted settler interests and depicted indigenous people as threatening, associating them with violence to discredit their struggle for land and rights (Ballara 1986; Harding 2006; Meadows 2004; Weston 1996). Printing presses were part of the colonial plan, operating in many settlements from the earliest times (Colvin 2010; Day 1990) to legitimate the settler state and to maintain surveillance (Harding 2006; Rankine et al. 2009) over the natives.

This history of ethnic relations has created the conditions within which Māori are over-represented in official crime statistics in many categories (Department of Corrections 2007), but a range of social characteristics influence the statistics (Webb 2009). For example, aside from differences in demography, such as a lower average age and life expectancy (Ministry of Social Development 2010), lower socioeconomic status (Perry 2009) and marked health disparities (Robson 2008), there are systematic distortions in the policing and sentencing of Māori that contribute to these official statistics of offending (Fergusson, Horwood and Swain-Campbell 2003; Te Puni Kokiri 2000). Māori have expressed strong distrust towards the Police force, viewing it as a racist institution with strong anti-Māori attitudes that perpetuates the colonial relationship between the State and Māori (Te Whaiti and Roguski 1998).

\section{CRIME REPORTING AND INDIGENOUS PEOPLE}

News media in former European colonies have persistently used ethnic labels for indigenous people accused of crimes, while failing to label people from dominant cultures (Fergusson, Horwood and Swain-Campbell 2003; Maxwell et al. 2004; Te Puni Kokiri 2000). Henry and Tator $(2006,203)$ argue that racial profiling in the media '...does not keep its citizens safer from violence, because it is an act of violence itself'. Memmi's notion of the 'mark of the plural' (Memmi 1965, 85) is relevant here, highlighting the coloniser's view of the 
colonised as an undifferentiated entity in which negative individual actions are attributed to the group as a whole (McCallum 2007).

In Australia, ethnic labelling breaches journalistic ethics around criminal justice but the practice is widespread (Ewart 1997), reflecting an underlying assumption that '.. the Aboriginal face in the newspaper is a criminal face' (Sercombe 1995, 89). For instance, newspaper studies have found that depictions of Aboriginal involvement with the criminal justice system were a dominant feature of coverage of Aboriginal issues (Edmunds and James 1991; Sercombe 1995). In representing indigenous people as criminal, Australian news media regularly depicted the police as neutral reliable sources (Budarick and King 2008; Gargett 2005; Grabosky and Wilson 1989; Storr 2009). Promulgating this construction of the indigenous as criminal and violent may encourage those who wish to make a political case for ignoring indigenous aspirations and values.

Researchers have argued that dominant news media constructions of indigenous crime benefit media and Police political agendas (McCallum 2007); divert attention from government inadequacies (Anti-Discrimination Board of New South Wales 2003); legitimise coercive and violent measures against indigenous people (Human Rights and Equal Opportunity Commission 1991) and undermine indigenous struggles for land rights. In contrast, Indigenous news media construct crime differently, positioning incidents within a context of ongoing social injustice and poor indigenous policy (Budarick and King 2008), or by depicting supposedly crime-ridden remote communities as sites of happiness, creativity and strength (Slater 2008).

\section{CRIME REPORTING AND MĀORI}

Reporting race-labelled crime has a long history in press coverage in this country, with an early study including it among a number of negative themes about Māori in a large newspaper sample: 'The high crime rate whereby a [Māori] minority in the community provides such a disproportionate amount of court cases, the different sex code of the Maori with the ensuing sex offences and the heavy consumption of liquor' (Thompson 1954, 4). Thompson (1954) argued that the underlying stressors of colonisation and the then current pressures of urbanisation were a likely cause for the differential. He added that journalists were strongly influenced by social understandings and were responsible for representing Māori in stereotyped and decontextualised ways. News media coverage in Aotearoa New Zealand has constructed periodic moral panics that position Māori as threatening or violent. Kelsey and Young (1982) provided an 
analysis of the way in which these constructions led to an increased emphasis on hard-line policing, supported repressive laws and severe sentences, while scapegoating gangs and avoiding challenges to state policies.

Māori crime statistics are 'newsworthy' to conventional newsmakers in the sense that they appear aberrant, deviant and anti-social (McGregor 2002) and journalists, using their occupational ideology, argue that reporting of Māori crime merely reflects objective reality (Nairn et al. 2009). Crime news in general has been shown to be increasing as a proportion of New Zealand news reporting (McGregor 1993, 2002; McGregor and Comrie 1995).

Newspapers in Aotearoa New Zealand use ethnic labels for Māori and Polynesian crime suspects up to four times more often than European or Caucasian (Spoonley 1989). One study identified a widespread failure of editors to observe their own house rules about ethnic labelling, and the low priority given to the issue by the Press Council (Kernot 1990). Police news releases are more likely to label suspects as Māori than Caucasian, and more likely to use physical descriptions of Pākehā suspects than ethnic labels (Rankine 2008). They also tend to emphasise the Māori rather than Pākehā ancestry of suspects by using terms such as 'part-Māori'. Elsewhere we have argued that 'Māori Crime' is a common trope or theme within a hegemonic discourse about the relationships between Māori and non-Māori; relationships that, within a colonial society, are of fundamental importance to social justice, national identity and political stability (McCreanor 2008).

Several common news media themes depict Māori as threatening to nonMāori (Moewaka Barnes et al. 2005; Rankine et al. 2008). These include the 'Māori Violence' theme, which portrays Māori as more likely to be violent (Keenan 2000); the 'Stirrers theme', which depicts Mãori who challenge the status quo as troublemakers; the 'Good Māori/Bad Māori' theme, which portrays Māori who resist, demand recognition or seek restitution as bad; and the 'Māori Resources' theme, which constructs potential or actual Māori control of land, fisheries or money as a threat to others. The 'Financial Probity' theme involves persistent depictions of Māori as corrupt or economically incompetent. These news media themes reproduce persistent public discourses (McCreanor 2008, 89-93).

In Aotearoa New Zealand, this marginalising of Māori voices and perspectives has focussed Māori attention on establishing separate Māori or iwi broadcast media and magazines. These demonstrate different news values, including a focus on self-determination and a voice independent of Government policies, 
more positive news, more issue-oriented stories, more background and context, more time for sources to speak and less adversarial interviewing (Stuart 2003; Te Awa 1996).

\section{METHOD}

Our project collected a representative sample of print, radio, and television news items relating to Māori and Māori/Pākehā relations in the six months between November 2007 and April 2008. Twenty-one sampling days, a random selection of three of each of the days of the week, created three 'constructed weeks', an enhancement of the two constructed weeks recommended for this purpose by Lacy et al. (2001).

Print data were collected by a professional clipping service working to a set of 15 keywords or phrases, including Maori, iwi, hapu, whanau, Treaty of Waitangi, and Māori-Pākehā relations. The items were gathered from every New Zealand daily, bi-weekly or weekly newspaper (a total of 120 titles), resulting in a raw data set of 1,621 items. Items were supplied to the team as photocopies of the original story, complete with headlines, any photographs, page numbers and a graphic showing its location on the page. A selection process identified stories that had a significant focus on Māori people and issues, excluding those where Māori interests were mentioned in passing as part of a wider topic: a Māori scholarship in a list of awards from a school prize-giving, naming the suburb of Maori Hill in Dunedin in a business item. The corpus was read by two of the researchers separately for a first cut of inclusions, exclusions and debateable items, before the selections were discussed and finalised by the team. This process resulted in a final database of 858 print media items that were coded to 16 topics developed iteratively from the reading of the items. An informal check of the effectiveness of the sampling suggested that our method produced an error rate of less than $4 \%$ (Rankine et al. 2014).

\section{FINDINGS}

We approached the analysis of the resulting database using techniques that would allow us to understand quantitative issues of prevalence and the thematic and discursive characteristics of the items. We discuss the substantive findings from each data and analysis set in turn before discussing the characteristics of print media crime reporting of Māori and relating this to overall media performance. 


\section{Content Analysis}

The 100 stories in the category 'Crime' were coded in an Access database by: page number and publication in which they appeared, whether daily or nondaily, the author, and the type - news or current affairs - and origin of items. Items were also coded for the number of people cited or quoted, whether sources were unavailable for comment, the ethnicity, role and gender of sources, the order in which sources were quoted and the number of sentences per source. The Crime items made up $12 \%$ of the sample, the second largest topic after Māori arts and more than twice the proportion of articles about Māori and sports (McCreanor et al. 2010).

Eighty-four crime items labelled Māori accused or convicted perpetrators of crime. Eighteen of these were stories about court cases or legal processes, where the accused or convicted people were identified as Mãori by their role: 'a general practitioner from the Waahi Health Centre at Waahi Pa in Huntly' and 'well-known for his role in Maori health' (New Zealand Herald 14 March 2008, 9). Crime stories were shorter on average than other stories, making up $7 \%$ of the total sentences in the entire sample. They were published by 44 newspapers, $37 \%$ of the 120 represented in the total sample. For seven small papers, crime stories made up half or more of their stories about Māori. For another five, crime stories made up one third of their Māori stories. The highest proportion of crime among Māori stories in a city newspaper was eight out of 29 (28\%).

Twenty-five crime stories, largely those asking readers to provide information about a particular crime, named no sources for their information. Unsourced crime stories made up $17 \%$ of the total 151 unsourced stories in the whole sample, so that the crime topic was the second-largest group of unsourced items after arts. The remaining 75 crime stories used 135 sources, making an average of 1.35 over all the crime stories, lower than the average for the whole sample (1.7). Crime sources made up $9 \%$ of the total sources for all Māori stories. The low source average also reflects reporters' routine reliance on a police or justice system source for such items.

Crime stories had the highest proportion of any topic with Pākehā sources only, making up 22\% of stories that used only Pākehā sources. Out of the 105 crime stories where ethnicity of sources was known, 66\% were Pākehā and $18 \%$ Māori. Almost half of the Māori sources were from the police or justice system; these government sources made up 62 percent of crime sources by role. Seventy-nine percent of sources were male compared to the proportion of male sources for the sample (63\%). 
While a smaller proportion of crime stories (5\%) were printed on the front page than all stories (8\%), $66 \%$ of crime stories were printed on news pages two to five compared with $40 \%$ for the whole sample. News pages six to 10 hosted $17 \%$ of crime stories (compared with $21 \%$ ); later news pages $7 \%$ (23\%), with five percent on non-news pages ( $7 \%)$. Three times as many Crime stories $(36 \%)$ were sourced from the NZ Press Association compared to the total number of Mãori items (12\%). Of the 156 people accused, sought or arrested for crimes, almost half (76) were identified as Māori, including one 'part-Maori' and another 'Caucasian or light-skinned Maori'. Thirty offenders were described as 'Maori or Polynesian/ Pacific Islander'. Only 12 were labelled with an ethnicity not Māori - one 'Pacific Islander'; 10 Australian teenage attackers identified as 'white boys' by their dead victim's mother; and greenstone thief David Saxton, identified as 'pakeha' in one item. Five offenders who were sought by Police were identified by description only, with no ethnicity: 'a man in his early 20 s who has a shaved head and a medium build'; one 'about 60 , thin, with no teeth'; a 'solidly-built male with an afro hairstyle'; a 'medium to heavy build female with long dark hair', and 'a male of similar age and build' to his young, heavy, Māori fellow offender. The other 33 people who were not identified by ethnicity had been arrested or referred to youth aid.

\section{Thematic Analysis}

This analysis examined all 100 crime stories, but also re-examined the raw dataset and gathered in 10 additional items, such as opinion columns, stories about crime prevention and other initiatives that seem relevant to understanding newspaper representations of Māori and crime in the widest possible sense. We grouped the 110 stories into clusters with characteristics in common to facilitate the analysis of themes. The analyses describe the main ideas running through the clusters of stories.

Table 1. Crime story thematic clusters $(n=110)$

\begin{tabular}{l|c}
\hline Police notices & 64 \\
\hline Against Māori & 18 \\
\hline Court reports & 17 \\
\hline Prevention & 8 \\
\hline Opinion & 3 \\
\hline
\end{tabular}




\section{Police Notices}

These stories consisted of two groups, 53 short notices (including combinations of multiple notices) about crimes that had been committed, and 11 longer stories which gave victim accounts in much more detail. The short notices took an almost standard form with a brief outline of the crime and a description of the alleged perpetrator, usually from a police source.

Nelson police were yesterday hunting for a man after a vicious baseball bat attack on two teenagers in an inner-city park...The attacker, described as a Maori, aged 25 to 35, of solid build with short, wavy hair, left before police arrived. (The Press 01 February, 2008, 4).

Longer stories achieved the same association between Māori identity and criminal behaviour, but reinforced the message through the human impact of the crime in personal loss, injury or fear.

\section{Court Reports}

Thirteen of the 17 items in this cluster related to the conviction of teacher Heremaia Smith on sex charges, making it the most frequent item in our crime sub-sample. The remaining four items were accounts of court convictions for various mostly petty crimes.

\section{Crimes Against Māori}

Eighteen items covered three stories; two clusters maintained the association between Māori and crime even though they reported crimes against Māori. Seven stories on the disappearance of Jim Wright exemplify the link as they used a similar format to Police notices: 'Police are concerned for the safety of a Feilding man who has been missing since January. Bevan William Wright, 43 ... is described as Maori, with short hair, $174 \mathrm{~cm}$ tall and of medium build' (Timaru Herald 23 February 2008, 3 ).

The third cluster of seven stories about the theft of pounamu from South Island iwi Ngai Tahu worked actively to re-cast the perpetrators as victims of a justice system biased in favour of Māori. Four stories report the murder of a Māori man in Sydney. 
Prevention

Eight stories looked at different ways in which crime can be prevented, including plans for generic 'youth centres' in provincial towns, plus an after-school programme at a Māori meeting house complex. Others covered new police Māori liaison officers, Women's Refuge activities and measures planned for an urban town centre. All incorporated or targeted Māori with these interventions. These stories, while acknowledging the need and value of Māori engagement and participation, seemed to do so without the conventional themes about Māori crime.

\section{Opinion}

Three columns expressed diverse opinions about: links between colonisation, identity and crime; anti-Treaty views that blame Māori for crime; and Māori youth and crime. The first of these pieces contextualises crime to social justice while the other two mark crime as a Māori attribute.

\section{Discursive Analyses}

We chose two items to illustrate ways in which the discursive detail of reporting of crime news served to produce and reproduce damaging representations of Māori. We used the deconstructive close reading processes of discourse analysis (Fairclough 1995; Potter and Wetherell 1987; van Dijk 1988) to show the ways in which choices of vocabulary, structure and rhetoric influenced meaning making and interpretations of these items. Our analyses are contextualised to understandings of commonplace Pākehā interpretative repertoires (Potter and Wetherell 1987) or what Philo $(2007,179)$ refers to as 'the range of arguments which existed on an issue. We examined the coverage of the most frequent story about Māori crime and the accounts of the theft of pounamu.

\section{Heremaia Smith}

This was a high-profile case given widespread coverage (in metropolitan and provincial city dailies) that provided considerable detail that resonates strongly with a Pākehā interpretative repertoire about Māori crime that entails an inherent depravity, dishonesty and violence (McCreanor 2008). At the time of the alleged offences Smith was head of a Māori Studies department in a secondary school and shorter items about the case made the connection between the accused and Maoridom through his Māori first name and that position. The language used in these items was formal with little elaboration of context, 
creating a sense of 'business as usual' at the courthouse. The items noted that while found guilty of six 'sex charges' Smith was cleared of a further eight charges, including the most serious-'sexual violation'.

The students involved were reported as being 'teenage' females and the offences occurred between 2002 and 2006 creating a pattern that rendered the perpetrator the more reprehensible and abusive. While the jury was reported to have deliberated for 24 hours, several items noted that a number of jury members wept as the verdict was delivered. No explanation was given for this so readers were left with a rhetorical silence to fill.

Longer items reported that the offences involved six students taught by Smith within the Maori Studies Department at the school. While it was never stated and victim name suppression prevented any hints about their identity, it is a reasonable assumption that the students were mostly Mãori and therefore that these were probably 'Māori-on-Māori' offences. Such crime is widely understood to stand outside the context of racism and colonisation (including the reports of domestic violence and infanticide involving Māori) and keys into dominant discourses about the inherent brutality and inferiority of Māori. That the abuse occurred within a Maori Studies department, a key institution ostensibly devoted to the healthy renaissance and promulgation of Mãori culture and society, added to the political capital to be reaped from the story.

Given this dismal interpretative frame it was unsurprising that papers chose to publish detailed accounts of the behaviour that produced the charges (even using evidence relating to dismissed counts) that bordered upon the salacious.

Not guilty verdicts were returned on four charges relating to one complainant. She alleged sexual violation by Smith inserting his penis into her mouth, and three indecent assault charges alleging he rubbed her genitals with his hand, held her hand on his penis and touched her legs and shoulders (Gisborne Herald 23 February 2008, 6).

The use of the dismissed charges alongside those upheld by the court implied that the complainant was indeed involved in these activities and gave a measure of the journalist's outrage against him. This disgust at Smith's behaviour was also somewhat generalised in the New Zealand Herald coverage. It added the fact that Smith, after his dismissal from his job as head of Maori Studies, had been a volunteer coach to a girls' sports team at a Gisborne school and was working with children at a Mãori school when the police detained him, 
implying a failure of care by Māori institutions.

\section{Pounamu Theft}

The theft by two helicopter pilots of a large quantity of pounamu (nephrite or 'New Zealand jade' - a material prized by Māori for tools and decorative carving) that belonged to Ngai Tahu provided a different association of Māori and crime. Apart from an opinion piece by Tahu Potiki in the Christchurch Press, the coverage implicated Ngai Tahu, rather than the crime or the courts, in the incarceration of the convicted thieves. The seven items were occasioned by an aerial protest, given clearance to fly over Paparua prison, about the sentences given the offenders David and Morgan Saxton. Only one item identified David Saxton as Pākehā; the other six implied it by opposition to iwi interests. Six items appeared in South Island papers and one in a North Island provincial city paper, suggesting that most editors did not see the protest as of national interest.

Most items gave prominence to the 'more than two years' detention and the requirement that the offenders pay reparations to Ngai Tahu of $\$ 300,000$. As highlighted by the protest, supporters of the convicted men felt the sentences were unjust. The family spokesperson described the length of the prison terms as harsh compared to time served for crimes of violence, sexual offending, and drunk driving. As one item reported, she also highlighted a putative loss to the community created by the sentences and dismissed the value of the stolen property: 'When all's said and done it's only some green rock', Ms Zwarst said (Westport News 03 April 2008, 2).

Much of the negative representation of Ngai Tahu was carried by the journalists' copy with little source input. For example, one city paper feature story, headlined 'Jailing of rescue pilots leaves 'huge gap' in Haast', included short personal biographies that emphasised the convicted men's family and community service. It also described the systematic process the iwi used to catch those stealing their pounamu. Unsourced claims suggested that Ngai Tahu engaged private investigators, pressured the police to act on the information obtained and pursued the case with vigour: 'The unusual Crown prosecutions were instigated at the request of the South Island Maori iwi (tribe), Ngai Tahu' (Otago Daily Times 23 February 2008, 19).

This item also gave space to a past relationship between one of the offenders and a Ngai Tahu woman, as a possible source of legitimate right to the pounamu. While the presiding judge had found no such right, the item implied 
that the issue remained pertinent by giving space to the family spokesperson to comment:' It smacks of the underlying political issue of customary and Maori titles. They [the Saxtons] are being used as an example...' (Otago Daily Times 23 February 2008, 19).

Constructing Māori title as 'political' in this way involved an appeal to the common media theme of 'Māori privilege' (McCreanor 2008), which depicts Māori as having unwarranted and inequitable rights in society among which customary title is a prime example (McCreanor 2008). The suggestion that the offenders were being scapegoated challenges the integrity of the court.

With the community and family spokespeople, the journalists constructed a strong sense that things were not right in the trial and sentencing of the Saxtons. Ngai Tahu chairman Mark Solomon was quoted from earlier comments saying that the sentence was a warning to those who break the law. In the context of the item's strong endorsement of the offenders for their community work, this seemed harsh and adversarial. A follow up article also in the Otago Daily Times (3 April 2008, 15) about a trust-fund set up on behalf of the convicted men, gave considerable space to a spokesperson's outline of fund-raising activities and call for a boycott of Ngai Tahu businesses. The overall effect of the coverage was to valorise the offenders and disparage Ngai Tahu, reversing the usual media commitment to the victim against the offender.

\section{Focus Groups}

To gauge meaning-making practices of media audiences in Aotearoa New Zealand, the project ran a series of three focus group interviews with each of three Māori and four Tauiwi (non-Māori including Pākehā and more recent immigrants) groups, recruited through community contacts and networks. Discussions entailed a combination of semi-structured talk and group analysis of specific news items selected and presented to the groups by the researchers. Data were recorded, transcribed, coded and analysed thematically (Braun and Clarke 2006). Publications that detail the methods and broader findings from this strand are separately available (Gregory et al. 2011; Moewaka Barnes et al. 2013) and here we offer some comments focussed specifically around the topic of crime.

Discussions about media representations of Māori and crime were commonplace in both Māori and Tauiwi focus groups, spontaneously and in response to particular media items that were presented to them. However, while the groups broadly agreed that Māori were over-represented in crime stories in 
all media, there were important differences in what this meant to participants of different ethnicities.

Māori participants frequently talked about the ways in which negative portrayals of Mãori in the news impacted upon their sense of themselves. In this excerpt, the participant articulated a sense of the unfairness of the coverage, given that the vast majority of Māori are thoroughly law-abiding citizens.

$\mathrm{H}-$ : Exactly, because this is what we are portrayed as in the media, we are portrayed as gangs and violence and you know just negative things, Police Ten $7^{2}$ is like Maori and Polynesian nine times out of ten. What happened to New Zealanders, eh, talk about New Zealanders. (Māori Focus Group 2).

$\mathrm{H}$ — listed several ways in which she experiences Māori as being represented and elaborated with an example of infotainment that blurs the boundary between news and drama. Gangs and violence, which involve people of all ethnicities, come to be symbolic of Māori through their repeated over-representation in media stories. The final sentence acidly notes that the term New Zealander is often used to discount Māori assertions of their status as indigenous people, but vanishes where differential ethnic labelling pertains to crime or other negative statistics. There were many similar comments in Māori focus groups describing multiple ways in which participants felt implicated or blamed for the activities of a minority. The sense of injustice extended to law enforcement agencies such as the police and courts, which were widely seen as being biased against Māori. This combination created anxiety among law-abiding Māori citizens in routine encounters with the law or authority figures.

A second data segment from a different meeting presented another kind of impact.' $\mathrm{M}$ — : They (immigrants) get here then they see all those things like that and then we go to their dairies and we meet them and you know it's like you know they look at you in the wrong way' (Māori Focus Group 2). Here the emphasis is on the negative effects media representations have on the interactions between Māori and non-Māori. The specific case of immigrant attitudes drawn from media representations was one of many in which the reactions of others were perceived to involve stereotypical negative judgements about Māori violence, dishonesty, child abuse and drug use. One participant noted to general agreement that while such an analysis may sound 'paranoid' it was nevertheless a genuine reaction that has diverse possible psychological effects, including guilt and anxiety. 
Tauiwi ${ }^{3}$ participants showed a keen awareness of the media depictions of Māori. This excerpt from a participant with English as a second language, neatly complements what $\mathrm{M}$ said above: ' $\mathrm{D}$ — : When the majority of the minority commit something, for example like the majority of Maori do a lot of violent crimes in the society, then nobody interest to learn about Maori culture' (Tauiwi focus group).

Ethnic labelling of crime was widely acknowledged by participants as unevenly applied. Participants noted that it was rare to find crime attributed to Pākehā, European or White. Another participant spelled out the perceived imbalance in some detail. 'R—: I think we all know it's about crime and stuff. If you have no contact with Maori, all you get in the media is the crime rates - all those sort of statistics are always in the paper. You never hear any good stories' (Pākehā focus group). Both Māori and non-Māori audience members saw the mass news media as inadequate and biased in their representations of Māori and crime in ways that were congruent with what we have described from content, thematic and discursive analyses of the data. Their comments illustrated a widespread interweaving of these characteristics between news coverage and infotainment genres such as Police Ten 7 . A number of participants said their perceptions of Māori crime were negatively influenced by the style and imbalance of reporting.

\section{DISCUSSION}

As in numerous historical analyses summarised above, the association between Māori and crime was prominent in this representative newspaper sample. The use of keyword search to select items will have under-counted such stories, since a proportion do not specify ethnicity which is often evident from offenders' names. We found that such items are more likely to appear in the first five pages of papers with larger circulation, and more likely than other news categories to be reprinted from outside a paper's area. The primary sources for these items were police and justice system representatives who were overwhelmingly Pākehā and male. Iwi and other independent Māori voices were rarely given space to comment and news about Māori and crime was isolated from social context. Non-Māori sought for crimes were typically described by appearance rather than ethnicity.

Our thematic analysis showed that 64 of the 112 items were police notices that made explicit but typically unsourced links between Māori ethnicity and crime; links unfiltered by 'traditional journalistic verification processes' (McGregor 1993, 4). A further 19 items were court reports in which newspapers 
provided plentiful ethnicity cues about accused Māori. Discursive analyses of very different stories show that the detail of the language and structure of the items produces meanings that impact negatively on Māori communities. These not-so-subtle effects are grounded on representations of Māori that are co-produced by media accounts that rely on and revivify the hegemonic discursive resources of the Pākehā readers and the journalists. Focus group data suggest that both Māori and Tauiwi audience members are aware of the media association of Māori and crime, but that the meaning of such materials is different for these groups.

We argue that this endless parade of mundane, 'below the radar' stories about ethnically-labelled crime in our newspapers is an easily overlooked but crucial component in the maintenance of negative societal stereotypes and discourses about Māori people and communities. Stories about Māori in our media are rare (Moewaka Barnes et al. 2005; Rankine et al. 2008; 2014) but a high proportion of them are about crime or are otherwise negative (Nairn et al. 2009).

The identified practices work in concert with other linguistic forms through which newspapers and other media define Māori as deviant and reproduce the normative values in the public life of Aotearoa New Zealand. As Archie (2007, 90) has said: '...we don't write about 'Pakeha leaders,' 'Pakeha activists' or 'Pakeha MPs'. But 'Maori leaders,' 'Maori activists' and 'Maori MPs' are part of the everyday news language.'

Phelan (2009) found that editorials about the foreshore and seabed issue $e^{4}$ used the identity label 'Maori' 44 times while Pākehā ethnicity was never mentioned; Pākehā interests were named as 'the public', 'the country', the 'national interest' or 'the Crown'. As Fleras and Spoonley $(1999,81)$ said of dominant groups: 'The institutions of which they are part, what they believe, and how they act are not culturally bound, but are viewed as natural, normal, and necessary'.

In this sense: 'Deviance, its control and its opposite, normality, are in fact the primary discursive objects of news making' (Jakubowicz et al. 1994, 27). Journalists use these normative positions and phrasings because they are pressed for time and these hegemonic resources are widely available; they are familiar with these resources outside their work; and assume them to be comprehensible to a broad spectrum of readers. Black (2004) calls this 'cultural blindness', the assumption that the dominant population works according to superior values, and that only other groups have culture. 
This omnipresent, unmarked Pākehā norm and the colonising perception of Māori as an undifferentiated group, explains the lack of ethnic labelling when media report a Pākehā person convicted, for example, of defrauding an organisation. Representations show Pākehā offenders as a 'bad apple' among the good, but when Māori do the same thing, ethnicity is cued and they represent all Māori. This invisible Pākehā norm would be obvious if Pākehā criminals were identified by ethnicity.

Ethnic labelling practices combined with persistent media positioning of Māori as a threat in stories around economic (resource control) and political (sovereignty) themes, represents part of a hegemonic discourse of MāoriPākehā relations, which heavily influences real-world marginalisation and discrimination against Māori in Aotearoa New Zealand. Media practitioners continue to wield extraordinary power to shape public opinion and mediate Māori/Pākehā relations. While the contemporary expressions of the marginalisation and dominance of Māori of the mass media are arguably more nuanced than their earlier renditions, they continue to do the racist work fundamental to the maintenance of the colonial state. Despite protestations that they merely reflect reality, they produce and reproduce Māori as deviant and threatening in what Gargett $(2005,1)$ has described as a 'continuing drone of colonialism' that seamlessly reproduces our historically unjust status quo.

NOTES

1 New Zealanders of European decent.

2 Police Ten $\mathrm{y}$ is a local 'reality' show that follows police on duty.

3 We use this term to encompass Pākehā New Zealanders and non-Pākehā, nonMāori New Zealanders.

4 The Crown legislated in 2004 to transfer all foreshore and seabed territories into State ownership despite the fact that they had never been legally acquired from their Māori owners.

\section{FUNDING}

The Media, Health and Wellbeing in Aotearoa study was funded by the Health Research Council of New Zealand. 


\section{REFERENCES}

Anti-Discrimination Board of New South Wales. 2003. Race for the headlines: Racism and media discourse. Sydney: ADBNsw.

Archie, C. 2007. Pou Korero: A Journalist's Guide to Maori and Current Affairs. Wellington: New Zealand Journalist's Training Organisation.

Ballara, A. 1986. Proud To Be White: A Survey of Racial Prejudice in New Zealand. Auckland: Heinemann.

Belich, J. 1996. Making Peoples: A History of the New Zealanders from Polynesian Settlement to the End of the Nineteenth Century. Auckland: Penguin.

Black, R. 2004. Marking the unmarked in Pākehā race talk. In Society of Australasian Social Psychologists Annual Conference, Hyatt Regency Hotel, Auckland, April.

Braun, V., and V. Clarke. 2006. 'Using thematic analysis in psychology'. Qualitative Research in Psychology 3 (2):77-101.

Budarick, J., and D. King. 2008. 'Framing ideology in niche media: The Koori Mail's construction of the Redfern riots.' Journal of Sociology 44 (4):355-371.

Chamberlain, K., and D. Hodgetts. 2008. 'Social psychology and media: critical considerations.' Social and Personality Psychology Compass 2 (3):1109-1125.

Colvin, G. 2010. The Soliloquy of Whiteness: Colonial Discourse and New Zealand's Settler Press 1839-1873, Christchurch: University of Canterbury.

$\mathrm{CsDH}$ [Commission on Social Determinants of Health]. 2007. Achieving health equity: From root causes to fair outcomes. Geneva: Commission on Social Determinants of Health, IER/EQH, World Health Organization.

Day, P. 1990. The making of the New Zealand press: a study of the organizational and political concerns of New Zealand newspaper controllers, 1840-1880. Wellington: Victoria University Press.

Department of Corrections. 2007. Over-representation of Maori in the Criminal Justice System: An Exploratory Report. Wellington: Police, Strategy and Research Group, Department of Corrections. 
Deuze, M. 2004. 'What is journalism? Professional identity and ideology of journalists reconsidered.' Journalism 6 (4):442-464.

Edmunds, M., and R. James. 1991. Black and white and read all over: Discourse, media and attitudes. Canberra: Australian Institute of Aboriginal and Torres Strait Islander Studies.

Ewart, J. 1997. 'The scabsuckers: Regional journalists' representation of indigenous Australians.' Asia Pacific Media Educator,3:108-117.

Fairclough, N. 1995. Media Discourse. London: Arnold.

Fergusson, D., L. Horwood, and N. Swain-Campbell. 2003. 'Ethnicity and Criminal Convictions: Results of a 21-year Longitudinal Study'. Australian and New Zealand Journal of Criminology 36 (3):354-367.

Fiske, J. 1994. Media matters: Everyday culture and political change. Minneapolis: University of Minnesota Press.

Fleras, A., and P. Spoonley. 1999. Recalling Aotearoa: Indigenous Politics and Ethnic Relations in New Zealand. Auckland: Oxford University Press.

Freng, A. 2007. 'American Indians in the news: A media portrayal in crime articles.' American Indian Culture and Research Journal 31 (1):21-37.

Furniss, E. 2001. 'Aboriginal justice, the media, and the symbolic management of Aboriginal/Euro-Canadian relations.' American Indian Culture and Research Journal 25 (2):1-36.

Gargett, A. 2005. 'A critical media analysis of the Redfern riot'. Indigenous Law Bulletin 18:1-7.

Grabosky, P., and P. Wilson. 1989. Journalism and justice: How crime is reported. Sydney: Pluto Press.

Gregory, M., B. Borell, T. McCreanor, A. Moewaka Barnes, R. Nairn, J. Rankine, S. Abel, K. Taiapa, and H. Kaiwai. 2011. 'Reading news about Maori: responses from non-Maori audiences.' AlterNative 7 (1): 51-64.

Hall, S. 1977. 'Culture, the media and the ideological effect.' In Mass Communication and Society, edited by J. Curran, M. Gurevitch and J. Woollacott, 315-349. 
London: Arnold.

Harding, R. 2006. 'Historical representations of aboriginal people in the Canadian news media.' Discourse \& Society 17 (2): 205-235.

Hartley, J. 1982. Understanding News. London: Methuen.

Henry, F., and C. Tator. 2002. Discourses of Domination: Racial Bias in the Canadian English-Language Press. Toronto: University of Toronto Press.

Henry, F., and C. Tator. 2006. Racial Profiling in Canada: Challenging the Myth of "A Few Bad Apples". Toronto: University of Toronto Press.

Human Rights and Equal Opportunity Commission. 1991. Racist Violence: Report of the National Inquiry into Racist Violence in Australia. Canberra: AGPS.

Jakubowicz, A., H. Goodall, J. Martin, T. Mitchell, L. Randall, and K. Seneviratne. 1994. Racism, Ethnicity and the Media. St Leonards: Allen and Unwin.

Keenan, D. 2000. 'Hine's once were warriors hell: The reporting and racialising of child abuse.' Social Work Review 12 (4):5-8.

Kelsey, J., and W. Young. 1982. The Gangs: Moral panic as social control. Wellington: Institute of Criminology, Victoria University of Wellington.

Kernot, B. 1990. 'Race-tagging: the misuse of labels and the Press Council.' In Between the Lines: Racism and the New Zealand Media. Auckland, edited by P. Spoonley and W. Hirsh, 53-55. Heinemann Reed.

King, M. 2003. The Penguin History of New Zealand. Auckland: Penguin.

Lacy, S., D. Riffe, S. Stoddard, H. Martin, and K.-K. Chang. 20o1. 'Sample size for newspaper content analysis in multi-year studies.' Journalism and Mass Communication Quarterly 78 (4):836-845.

Maxwell, G., J. Robertson, V. Kingi, A. Morris, and C. Cunningham. 2004. Achieving Effective Outcomes in Youth Justice: an Overview of Findings. Wellington: Ministry of Social Development.

McCallum, K. 2007. Indigenous violence as a 'Mediated Public Crisis'. Paper read at Communications, Civics, Industry - ANZCA2007 Conference Proceedings. 
McCreanor, T. 2008. 'Discourse, media and health in Aotearoa.' In Understanding Health Inequalities in Aotearoa New Zealand, edited by K. Dew and A. Matheson, 85-96. Dunedin: University of Otago Press.

McCreanor, T., J. Rankine, A. Moewaka Barnes, B. Borell, R. Nairn, M. Gregory, and H. Kaiwai. 2010. 'Maori sport and Maori in sport: mass media representations and pakeha discourse.' Alternative, 6 (3):235-247.

McGregor, J. 1993. Crime news as prime news in New Zealand's metropolitan press. Auckland: Legal Research Foundation.

McGregor, J. 2002. 'Crime news: The cutting edge.' In What's News: Reclaiming Journalism in New Zealand, edited by J. McGregor and M. Comrie, 81-95. Palmerston North: Dunmore Press.

McGregor, J., and M. Comrie. 1995. Balance and Fairness in Broadcasting News 1985-1994. Palmerston North: Massey University.

McGregor, J., and M. Comrie, eds. 2002. What's News? Reclaiming Journalism in New Zealand. Palmerston North: Dunmore Press.

Meadows, M. 2004. 'Media images of indigenous affairs in Australia.' In Outer limits: A reader in communication across cultures, edited by J. Leigh and E. Loo, 273-289. Melbourne: Language Australia.

Memmi, A. 1965. The Coloniser and the Colonised. Beacon Press: Boston.

Ministry of Social Development. 2010. The Social Report 2010 [consulted 2 March 2011]. Available from http://www.socialreport.msd.govt.nz/introduction/ index.html.

Moewaka Barnes, A., M. Gregory, T. McCreanor, R. Nairn, F. Pega, and J. Rankine. 2005. Media and Te Tiriti o Waitangi 2004. Auckland: Kupu Taea.

Moewaka Barnes, A., K. Taiapa, B. Borell, and T. McCreanor. 2013. 'Maori experiences and responses to racism in New Zealand.' MAI Journal 2 (2): 63-77.

Nairn, R., T. McCreanor, J. Rankine, A. Moewaka Barnes, F. Pega, and A. Gregory. 2009. "Media surveillance of the natives': A New Zealand case study-Lake Taupo air space.' Pacific Journalism Review 15 (1):131-148. 
Nickels, H., L. Thomas, M. Hickman, and S. Silvestri. 2012. 'De/constructing "suspect" communities.' Journalism Studies 13 (3):340-355.

Paradies, Y., and D. Williams. 2008. 'Racism and health.' In International Encyclopedia of Public Health, edited by S. Quah and K. Heggenhougen, 474-483. San Diego: Academic Press.

Perry, B. 2009. New Zealand Living Standards 2008. Wellington: Ministry of Social Development.

Phelan, S. 2009. 'The newspaper as political antagonist: Editorial discourse and the othering of Maori perspectives on the foreshore and seabed conflict.' Journalism 10 (2):217-237.

Phelan, S., and F. Shearer. 2009. 'The "radical", the "activist" and the hegemonic newspaper articulation of the Aotearoa New Zealand foreshore and seabed conflict.' Journalism Studies 10 (2):220-237.

Philo, G. 2007. 'Can discourse analysis successfully explain the content of media and journalistic practice?' Journalism Studies 8 (2):175-196.

Potter, J., and M. Wetherell. 1987. Discourse Analysis and Social Psychology: Beyond Attitudes and Behaviour. London: Sage.

Ramasubramanian, S. 2011. 'The Impact of Stereotypical Versus Counterstereotypical Media Exemplars on Racial Attitudes, Causal Attributions, and Support for Affirmative Action.' Communication Research 38 (4): 497-516.

Rankine, J. 2008. Submission to the review of crime and criminal justice statistics. Auckland.

Rankine, J., A. Moewaka Barnes, B. Borell, R. Nairn, and T. McCreanor. 2014. 'Content and source analysis of newspaper items about Māori issues: Silencing the 'natives' in Aotearoa?' Pacific Journalism Review in press.

Rankine, J., A. Moewaka Barnes, B. Borell, R. Nairn, T. McCreanor, and A. Gregory. 2009. 'Intentional use of te reo Māori in New Zealand newspapers in 2007.' Pacific Journalism Review 15 (2):174-190.

Rankine, J., R. Nairn, A. Moewaka Barnes, M. Gregory, H. Kaiwai, B. Borell, and T. McCreanor. 2008. Media \& Te Tiriti Waitangi 2007. Tamaki Makaurau/ 
Auckland: Kupu Taea: Media and Te Tiriti Project.

Reid, P., and R. Robson. 2007. 'Understanding health inequities.' In Hauora: Maori standards of health IV. A study of the years 2000-2005, edited by B. Robson and R. Harris, 3-10. Wellington: Te Ropu Rangahau Hauora a Eru Pomare.

Robson, B. 2008. 'What's driving the disparities?' In Inequalities in Aotearoa New Zealand, edited by K. Dew and A. Matheson, 19-31. Dunedin: Otago University Press.

Sercombe, H. 1995. 'The face of the criminal is Aboriginal: Representations of Aboriginal young people in the West Australian newspaper.' In Cultures of Crime and Violence: The Australian Experience, edited by J. Bessant, K. Carrington and S. Cook, 76-94. Melbourne: La Trobe University Press.

Slater, L. 2008. “Aurukun, we're happy, strong people’: Aurukun kids projecting life into bad headlines.' Borderlands, 7 (2):1-14. http://www.borderlands.net.au/ vol7no2_2008/slater_aurukun.pdf.

Spoonley, P. 1989. 'Challenge issued on Maori affairs.' New Zealand Journalism Review 2:35-37.

Storr, C. 2009. 'The Aurukun Rape Case, Indigenous Sentencing and the Normalisation of Disadvantage.' Australian Indigenous Law Review 13 (1):10-7113.

Stuart, I. 2003. 'The construction of a national Maori identity by Maori media.' Pacific Journalism Review 9:45-58.

Te Awa, J. 1996. 'Mana News: A case study'. Sites 33:168-175.

Te Puni Kokiri. 20oo. Ministry of Maori Development, Whanake Rangatahi: Programmes and Services to Address Maori Youth Offending. Wellington: Te Puni Kokiri.

Te Whaiti, P., and M. Roguski. 1998. Māori perceptions of the Police: He Pārekereke/ Victoria Link Ltd.

Thomas, V., and R. Green. 2009. 'Family violence reporting: supporting the vulnerable or reinforcing their vulnerability?' Asia Pacific Media Educator 19:55-70.

Thompson, R. 1954. 'Maori affairs and the New Zealand Press, Part II. Journal of 
the Polynesian Society 63 (1):1-16.

van Dijk, T. 1988. 'How they hit the headlines: ethnic minorities in the press.' In Discourse and discrimination, edited by G. Smitherman-Donaldson and T. Van Dijk, 221-262. Detroit: Wayne State University Press.

van Dijk, T. 1991. Racism and the press. London: Routledge.

Walker, R. 2004. Ka whawhai tonu matou, Struggle without end. Auckland: Penguin.

Ward, J. 1839. Information Relative to New Zealand. London: J.W. Parker.

Warren, D. 2012. 'Constructing "the Other”: Media Representations of Katrina Evacuees in Houston, Texas.' Race and Justice 2 (2): 93-113.

Webb, R. 2009. 'Māori, Pacific peoples and the social construction of crime statistics [Peer Commentary 2].' MaI Review 3:1-4.

Weston, M. 1996. Native Americans in the news: Images of Indians in the twentieth century press. Westport: Greenwood Press. 